\title{
Eksistensi Banul sebagai Kearifan Lokal Pelestarian Lingkungan oleh Lembaga Adat di Desa Tun'noe Kecamatan Miomaffo Timur
}

Fidelis Atanus ${ }^{\mathrm{a}}$, Theodorus Monaldus Yanuaris $\mathrm{Nabu}^{\mathrm{b}}$, dan Medan Yonathan Mael

${ }^{a}$ Fakultas Ilmu Sosial dan Ilmu Politik, Universitas Timor, Kefamenanu, TTU - NTT, Indonesia.

${ }^{b}$ Dinas Pendidikan, Pemuda, dan Olah Raga Kabupaten TTU, Kefamenanu, TTU - NTT, Indonesia.

${ }^{c}$ Fakultas Ilmu Sosial dan Ilmu Politik, Universitas Timor, Kefamenanu, TTU - NTT, Indonesia.

\section{Article Info}

\section{Article history:}

Received 4 Desember 2017

Accepted 28 Maret 2018

\section{Keywords:}

Banul

Kearifan Lokal

Pelestarian Lingkungan

Lembaga Adat

Tun'noe
Received in revised form 7 Maret 2018

\begin{abstract}
Abstrak
Banul merupakan salah satu kearifan lokal di desa Tun'noe, kecamatan Miomaffo Timur, kabupaten Timor Tengah Utara (TTU). Banul juga merupakan salah satu tradisi larangan adat yang masih berlaku di desa Tun'noe sampai sekarang dalam era otonomi daerah ini. Tujuan penelitian ini adalah mendapatkan gambaran tentang tingkat keteraturan, tingkat kepatuhan dan tingkat kesesuaian Banul di desa Tun'noe, kecamatan Miomaffo Timur, kabupaten TTU. Penelitian ini dilakukan pada bulan April sampai Juli 2017 di desa Tun'noe, kecamatan Miomaffo Timur, kabupaten TTU, menggunakan metode penelitian deskriptif kualitatif dengan pendekatan eksploratif. Pengambilan data dari lapangan digunakan beberapa teknik antara lain pengamatan yang mendalam (observasi), wawancara (interview) dan dokumen. Hasil penelitian menunjukkan bahwa keberadaan Banul dari aspek tujuannya sebenarnya cukup membantu masyarakat dalam mengelola lingkungan dan kesejahteraannya, selain itu Banul juga bernilai Sosial. Hal ini disebabkan karena dengan Banul maka kehidupan sosial masyarakat, panen dan keseimbangan lingkungan dapat diatur. Kepatuhan masyarakat terhadap Banul belum maksimal diterapkan karena perbendaan persepsi tentang hak milik terhadap apa yang dilarang. Di satu sisi ada hukum adat yang melarang namun disisi lain apa yang dilarang adalah kepemilikan pribadi atau suku. Seharusnya Banul tidak mengenal kepemilikan pribadi atau suku karena berkaitan dengan keseluruhan lingkungan atau ekosistem dan merupakan kesepakatan seluruh masyarakat. Tradisi Banul belum searah dengan hukum formal, sehingga perlu adanya peraturan daerah dan peraturan desa tentang pelestarian kearifan lokal untuk memperkuat eksistensi Banul. (c)2018 dipublikasikan oleh Agrimor.
\end{abstract}

\section{Pendahuluan}

Banul merupakan salah satu kearifan lokal di desa Tun'noe, kecamatan Miomaffo Timur, kabupaten Timor Tengah Utara (TTU). Banul juga merupakan salah satu tradisi larangan adat yang masih berlaku di desa Tun'noe sampai sekarang dalam era otonomi daerah ini. Banul itu sendiri tidak terlepas dari hukum adat, karena siapa saja penduduk desa Tun'noe yang melanggar past akan dikenakan sangsi atau dalam bahasa daerah disebut $o b$ yang sudah ditetapkan terlebih dahulu oleh lembaga adat dalam hal ini adalah tobe dalam satu kesepakatan bersama. Banul adalah suatu larangan adat atau norma ada yang mengatur sesuatu yang tidak boleh dilanggar oleh masyarakat di desa Tun'noe. Pelanggaran dimaksud adalah petik atau mengambil hasil hutan (asam, kayu cendana) sebelum waktunya, bercocok tanam (tebas kebun) sebelum waktunya, juga memanen hasil kebun (padi, jagung, jenis sayur-sayuran) sebelum waktu serta hasil kebun (kelapa, pinang, dan lainya).

Banul ada dan berasal dari prinsip keseimbangan alam, lahir dari salah satu hakikat terciptanya pandangan hidup manusia yaitu hakikat hubungan manusia dengan alam dimana alam dipandang sebagai "ibu" yang memberi kehidupan Oleh karena itu mewajibkan semua yang berada dalam dunia untuk menjaga dan melestarikannya. Pada tahap inilah lahirlah Banul atau larangan adat yang mengatur tentang cara menghargai dan menyelaraskan alam. Banul adalah larangan adat yang bersifat konstruktif demi keseimbangan alam dan kebahagiaan manusia.

Untuk menjaga keselarasan dan keseimbangan serta keseragaman dalam pelestarian, keseimbangan sosial dalam hidup bermasyarakat di desa Tun'noe, tobe bersama tokoh adat dan pemerintah melakukan suatu ritual adat penyerahan kepada para leluhur atau tuan tanah (tana'at neu pah) dengan sepenggal doa (toes) dalam kaitan dengan upacara Banul. Doa yang diucapkan oleh seorang tobe dalam bahasa daerah atau bahasa dawan adalah sebagai berikut:

"Hoe au usi amoet ma apaket, apinat ma aklat, pah tun'noe in tuana in am $i, n e o n ~ i$ ait an kit oef $i$ ma nafuf $i$ ne toitit he pau bale tola $i$ ma naijan $i$ he he te in olsat neu mnahat mninut ma namanaut ni heto bi neon namuin sufa kauf me et nait ma lab nahun hi et mi penje ma minoin'a a fela kai ao min' ma ansau mi'na, tonja ona le i basnat ona le $i$ "' yang dalam bahasa Indonesia dapat diartikan "Tuhan maha pencipta yang bercahaya juga para leluhur dan tuan tanah di wilayah ini, hari ini kami datang membawa persembahan in (ayam/babi) untuk meminta menjaga tempat ini (kebun, hasil perkebunan, hasil hutan, sumber air) dari anak cucu yang sengaja mengambil maka kenakanlah teguran kepadanya, kami minta berkat kesehatan, kedamaian bagi kami, demikian permohonan kami sampai di sini.'

Biasanya sebelum melakukan ritual adat ini akan diadakan musyawarah bersama dan mengundang semua kepala suku yang ada untuk hadir bersama dalam upacara tersebut, hewan sembelihan juga menjadi tanggung jawab bersama.

Barang siapa yang melanggar Banul ini akan di kenakan sanksi adat oleh tobe yang sebelumnya sudah ditentukan bersama. Sanksi adat itu ada bermacammacam sesuai berat ringannya pelanggaran yang dibuat. Pelanggaran yang paling berat itu dikenakan sanksi berupa satu ekor babi besar, beras lima puluh kilogram, sopi dua karfaun, semua itu akan dibuatkan ritual adat dan makan minum bersama (tauf tob), sedangkan yang paling ringan berupa ayam satu ekor, dan sopi satu botol.

Berbagai kebijakan lembaga adat terkait upaya penyelesaian masalah Banu sampai sekarang tidak terlepas dari perhatian pemerintah desa Tun'noe, karena lembaga adat itu sendiri tidak terlepas dari pemerintahan desa bagaikan dua sis mata uang yang tidak dapat dipisahkan. Namun khusus untuk perhatian dari pemerintahan kabupaten maupun provinsi masih sangat kurang. Pemerintah lebih berorientasi pada masalah-masalah yang ada di desa. Pada dekade terakhir ini peran dari lembaga adat dalam pembangunan, pelestarian alam, sistem bertani dan penyelesaian masalah di desa sangat besar namun tingkat kepatuhan terhadap Banul makin menipis. Hal ini dilihat dari acuhnya masyarakat khususnya generasi muda menghargai dan menaati Banul. Contohnya adanya kesepakatan adat untuk tidak memetik buah secara sembarangan dan diatur pada musim yang disepakati tetapi generasi muda tidak memedulikan bahkan melanggar dengan memetik buah seperti kelapa, pinang dan buah-buahan lainnya yang dilarang. Dalam konteks ini eksistensi lembaga adat kian hari makin pudar bahkan hilang. Selain itu juga penyelesaian masalah-masalah sosial melalui lembaga adat belum mendapat tempat yang sepatutnya dimana lembaga adat yang mengurus masalah masalah sosial dianggap kuno dan ketinggalan jaman. Kelembagaan Banul sepenuhnya adalah kewenangan lembaga adat dalam hal ini adalah tobe Seharusnya, melalui tobe penyelesaian masalah Banul yang dilanggar oleh masyarakat akan menerimanya dengan lapang dada tanpa bantahan, keberatan juga tidak ada kata-kata pembelaan maupun upaya pendekatan secara perorangan. Namun hal ini telah jauh dari harapan.

Banul tidak terlepas dari hukum. Hukum mempunyai kaitan erat dengan sistem pemerintahan, karena bersama-sama bertujuan untuk mengintegrasikan dan mengarahkan kehidupan masyarakat sesuai idealisme. Eksistensi lembaga adat dalam upaya pelestarian Banul pada era otonomi daerah dalam tingkat pemerintahan yang paling bawah dan paling dekat pada rakyat yaitu pada pemerintahan desa memiliki peran terbesar dalam hal pelestarian Banul, untuk itu perlu dilakukan penelitian dengan topik "Eksistensi Banul sebagai Kearifan Lokal Pelestarian Lingkungan oleh Lembaga Adat di Desa Tun'noe Kecamatan Miomaffo Timur". Tujuan penelitian ini adalah mendapatkan gambaran tentang tingkat keteraturan, tingkat kepatuhan dan tingkat kesesuaian Banul di desa Tun'noe, kecamatan Miomaffo Timur, kabupaten TTU.

\section{Metode}

Penelitian ini dilakukan pada bulan April sampai Juli 2017 di desa Tun'noe, kecamatan Miomaffo Timur, kabupaten TTU. Penelitian ini menggunakan metode penelitian deskriptif kualitatif dengan pendekatan eksploratif yakni peneliti ingin mengeksplor fenomena-fenomena alamiah, menggali kenyataankenyataan yang belum terungkap, mendeskripsikan suatu keadaan yang sebenarnya dan menginterpretasikannya berdasarkan metode dan proses-proses analisis data. Fokus penelitian ini adalah tingkat keteraturan, tingkat kepatuhan dan tingkat kesesuaian Banul. Informan dalam penelitian ini adalah aparatur pemerintah desa Tun'noe, tokoh-tokoh adat, lembaga adat yang melakukan Banul dan masyarakat desa Tun'noe.

Pengambilan data dari lapangan digunakan beberapa teknik antara lain pengamatan yang mendalam (observasi), wawancara (interview) dan dokumen. Miles and Huberman yang dikutip Sugiyono, (2006) mengemukakan bahwa aktivitas dalam analisa data kualitatif dilakukan secara interaktif dan berlangsung secara terus menerus sampai tuntas, sehingga datanya sudah jenuh. Adapun tahap-tahap analisis datanya adalah data collection (koleksi data), data reduction (reduksi data), data display (penyajian data), dan conclusions drawing/verification.

\section{Hasil dan Pembahasan \\ 3.1 Tingkat Keteraturan Banul}

Banul cukup membantu masyarakat dalam mengelola lingkungan dan kesejahteraannya, selain itu Banul juga bernilai Sosial. Hal ini disebabkan karena Banul dapat mengatur kehidupan, mengatur panenan dan mengatur keseimbangan lingkungan. Banul merupakan salah satu kearifan lokal yang perlu dilestarikan dan dijaga. Kearifan lokal menurut Undang-Undang Nomor 32 tahun 2009 
tentang Perlindungan dan Pengelolaan Lingkungan Hidup dalam BAB I Pasal 1 butir 30 adalah "nilai-nilai luhur yang berlaku dalam tata kehidupan masyarakat untuk antara lain melindungi dan mengelola lingkungan hidup secara lestari". Selanjutnya Liliweri, (2003) memaparkan bahwa kearifan lokal atau sering disebut local wisdom dapat dipahami sebagai usaha manusia dengan menggunakan akal budinya (kognisi) untuk bertindak dan bersikap terhadap sesuatu, objek, atau peristiwa yang terjadi dalam ruang tertentu.

Selanjutnya Keraf, (2010) memberikan uraian bahwa kearifan lokal bukan hanya menyangkut pengetahuan dan pemahaman masyarakat adat tentang manusia dan bagaimana relasi yang baik di antara manusia, melainkan juga menyangkut pengetahuan, pemahaman dan adat kebiasaan tentang manusia, alam dan bagaimana relasi di antara semua penghuni komunitas ekologis ini harus dibangun. Seluruh kearifan tradisional ini dihayati, dipraktikkan, diajarkan dan diwariskan dari satu generasi ke generasi lain yang sekaligus membentuk pola perilaku manusia sehari-hari, baik terhadap sesama manusia maupun terhadap alam dan Yang Gaib. Hal tersebut menunjukkan bahwa 1) kearifan tradisional adalah milik komunitas. Demikian pula, yang dikenal sebagai pengetahuan tentang manusia, alam dan relasi dalam alam juga milik komunitas. Tidak ada pengetahuan atau kearifan tradisional yang bersifat individual; 2) kearifan tradisional, yang juga berarti pengetahuan tradisional, lebih bersifat praktis, atau "pengetahuan bagaimana". Pengetahuan dan kearifan masyarakat adat adalah pengetahuan bagaimana hidup secara baik dalam komunitas ekologis, sehingga menyangkut bagaimana berhubungan secara baik dengan semua isi alam. Pengetahuan ini juga mencakup bagaimana memperlakukan setiap bagian kehidupan dalam alam sedemikian rupa, baik untuk mempertahankan kehidupan masing-masing spesies maupun untuk mempertahankan seluruh kehidupan di alam itu sendiri. Itu sebabnya, selalu ada berbagai aturan yang sebagian besar dalam bentuk larangan atau tabu tentang bagaimana menjalankan aktivitas kehidupan tertentu di alam ini; 3) kearifan tradisional bersifat holistik, karena menyangkut pengetahuan dan pemahaman tentang seluruh kehidupan dengan segala relasinya di alam semesta. Alam adalah jaring kehidupan yang lebih luas dari sekedar jumlah keseluruhan bagian yang terpisah satu sama lain. Alam adalah rangkaian relasi yang terkait satu sama lain, sehingga pemahaman dan pengetahuan tentang alam harus merupakan suatu pengetahuan menyeluruh; 4) berdasarkan kearifan tradisional dengan ciri seperti itu, masyarakat adat juga memahami semua aktivitasnya sebagai aktivitas moral. Kegiatan bertani, berburu dan menangkap ikan bukanlah sekedar aktivitas ilmiah berupa penerapan pengetahuan ilmiah tentang dan sesuai dengan alam, yang dituntun oleh prinsipprinsip dan pemahaman ilmiah yang rasional. Aktivitas tersebut adalah aktivitas moral yang dituntun dan didasarkan pada prinsip atau tabu-tabu moral yang bersumber dari kearifan tradisional; dan 5) berbeda dengan ilmu pengetahuan Barat yang mengklaim dirinya sebagai universal, kearifan tradisional bersifat lokal, karena terkait dengan tempat yang partikular dan konkret. Kearifan dan pengetahuan tradisional selalu menyangkut pribadi manusia yang partikular (komunitas masyarakat adat itu sendiri), alam (di sekitar tempat tinggalnya) dan relasinya dengan alam itu. Tetapi karena manusia dan alam bersifat universal, kearifan dan pengetahuan tradisional dengan tidak direkayasa pun menjadi universal pada dirinya sendiri. Kendati tidak memiliki rumusan universal sebagaimana dikenal dalam ilmu pengetahuan modern, kearifan tradisional ternyata ditemukan di semua masyarakat adat atau suku asli di seluruh dunia, dengan substansi yang sama, baik dalam dimensi teknis maupun dalam dimensi moralnya.

Dengan kemampuan Banul dalam mengatur kehidupan, mengatur panenan dan mengatur keseimbangan lingkungan maka dapat disimpulkan bahwa Banul merupakan salah satu kearifan lokal yang memiliki keteraturan dan perlu dilestarikan dan dilindungi oleh pemerintah.

\subsection{Tingkat Kesesuaian Banul}

Hasil penelitian berkaitan dengan tingkat kesesuaian Banul menunjukkan bahwa kurangnya sinergitas antara hukum formal dan hukum adat tentang Banul dimana hukum adat mewajibkan bagi pelanggar hukum adat untuk dikucilkan atau dikeluarkan dari desa Tun'noe namun hal ini bertentangan dengan hukum formal atau dengan kata lain tradisi Banul belum maksimal searah dengan hukum formal. Hal ini dilihat dari sanksi-sanksi yang bersifat jera belum searah dengan hukum formal.

Desa menurut Undang-Undang Nomor 6 Tahun 2014 tentang Pemerintahan Daerah mengartikan desa sebagai "desa atau yang disebut nama lain, selanjutnya disebut desa, adalah kesatuan masyarakat hukum yang memiliki batas-batas wilayah yang berwenang untuk mengatur dan mengurus kepentingan masyarakat setempat, berdasarkan asal-usul dan adat istiadat setempat yang diakui dan dihormati dalam sistem Pemerintah Negara Kesatuan Republik Indonesia.

Dalam pengertian desa di atas sangat jelas sekali bahwa desa merupakan Self Community yaitu komunitas yang mengatur dirinya sendiri. Dengan pemahaman bahwa desa memiliki kewenangan untuk mengurus dan mengatur kepentingan masyarakatnya sesuai dengan kondisi dan sosial budaya setempat, maka posisi desa yang memiliki otonomi asli sangat strategis sehingga memerlukan perhatian yang seimbang terhadap penyelenggaraan Otonomi Daerah. Karena dengan Otonomi desa yang kuat akan mempengaruhi secara signifikan perwujudan Otonomi Daerah. Wujudnya melalui penempatan adat istiadat pada tempatnya (Huda, 2014).

Adat selalu menyesuaikan diri dengan keadaan dan kemajuan zaman, sehingga adat itu tetap kekal, karena adat selalu menyesuaikan diri dengan kemajuan masyarakat dan kehendak zaman. Adat-istiadat yang hidup di dalam masyarakat erat sekali kaitannya dengan tradisi-tradisi rakyat dan ini merupakan sumber pokok dari pada hukum adat (Salim, 2015). Menurut Juliantara, (2003) adat adalah tingkah laku yang oleh masyarakat diadatkan. Adat ini ada yang tebal dan ada yang tipis dan senantiasa menebal dan menipis. Aturan-aturan tingkah laku di dalam masyarakat ini adalah aturan adat dan bukan merupakan aturan hukum.

\subsection{Tingkat Kepatuhan terhadap Banul}

Berkaitan dengan tingkat kepatuhan masyarakat terhadap Banul ditemukan bahwa Banul belum maksimal diterapkan karena perbendaan persepsi tentang hak milik terhadap apa yang dilarang. Di satu sisi ada hukum adat yang melarang namun disisi lain adalah kepemilikan pribadi atau suku. Seharusnya Banul tidak mengenal kepemilikan pribadi atau suku karena berkaitan dengan keseluruhan lingkungan atau ekosistem dan merupakan kesepakatan seluruh masyarakat.

Maskun, (2002) mendefinisikan hukum adat adalah endapan kesusilaan dalam masyarakat yaitu kaidah-kaidah kesusilaan yang kebenarannya telah mendapat pengakuan umum dalam masyarakat itu. Hal ini dipertegas oleh Juliantara, (2003) bahwa hukum adat adalah suatu kompleks norma-norma yang bersumber pada perasaan keadilan rakyat yang selalu berkembang serta meliputi peraturan-peraturan tingkah laku manusia dalam kehidupan sehari-hari dalam masyarakat, sebagian besar tidak tertulis, senantiasa ditaati dan dihormati oleh rakyat karena mempunyai akibat hukum (sanksi). Hal yang sama juga disampaikan oleh Soemardjan, (1990), bahwa hukum adat adalah hukum tidak tertulis di dalam peraturan tidak tertulis, meliputi peraturan-peraturan hidup yang meskipun tidak ditetapkan oleh yang berwajib tetapi ditaati dan didukung oleh rakyat berdasarkan atas keyakinan bahwasanya peraturan-peraturan tersebut mempunyai kekuatan hukum.

Secara umum dapat dikatakan bahwa masyarakat kurang mematuhi kesepakatan yang menjadi hukum adat dalam Banul. Sebenarnya hukum adat prinsipnya tidak tertulis namun wajib ditaati dalam kehidupan bersama sebagai sebuah sistem nilai yang mengarahkan masyarakat kepada kebaikan bersama.

\section{Simpulan}

Keberadaan Banul dari aspek tujuannya sebenarnya cukup membantu masyarakat dalam mengelola lingkungan dan kesejahteraannya, selain itu Banul juga bernilai Sosial. Hal ini disebabkan karena dengan Banul maka kehidupan sosial masyarakat, panen dan keseimbangan lingkungan dapat diatur. Kepatuhan masyarakat terhadap Banul belum maksimal diterapkan karena perbendaan persepsi tentang hak milik terhadap apa yang dilarang. Di satu sisi ada hukum adat yang melarang namun disisi lain apa yang dilarang adalah kepemilikan pribadi atau suku. Seharusnya Banul tidak mengenal kepemilikan pribadi atau suku karena berkaitan dengan keseluruhan lingkungan atau ekosistem dan merupakan kesepakatan seluruh masyarakat. Tradisi Banul belum searah dengan hukum formal, sehingga perlu adanya peraturan daerah dan peraturan desa tentang pelestarian kearifan lokal untuk memperkuat eksistensi Banul.

\section{Pustaka}

Huda, A. 2014. Kesejahteraan Masyarakat Pasca Pemekaran Desa (Studi pada Desa Sumberbrantas, Kota Batu). Jurnal Administrasi Publik, 2(4): 627633.

Juliantara, D. 2003. Pembahuruan Desa, Bertumpu pada Angka Terbawah. Yogyakarta: Lappera Pustaka Utama.

Keraf, A.S. 2010. Etika Lingkungan Hidup. Jakarta: Penerbit Buku Kompas. Liliweri, A. 2003. Makna Budaya dalam Komunikasi Antarbudaya. Yogyakarta: PT LKiS Pelangi Aksara.

Maskun, S. 2002. Otonomi Daerah Peluang dan Tantangan. Jakarta: Pustaka Sinar Harapan.

Salim, M. 2015. Adat Recht sebagai Bukti Sejarah dalam Perkembangan Hukum Positif di Indonesia. Al Daulah: Jurnal Hukum Pidana dan Ketatanegaraan, 4(1): 16-31.

Soemardjan 1990. Sosiologi Suatu Pengantar. Jakarta: PT Raja Grafindo Persada.

Sugiyono, 2006. Metode Penelitian Kuantitatif, Kualitatif dan $R \& D$. Bandung: Alfabeta.

Undang-Undang Nomor 32 Tahun 2009 tentang Perlindungan dan Pengelolaan Lingkungan Hidup.

Undang-Undang Nomor 6 Tahun 2014 tentang Pemerintahan Daerah. 